JURIDICAL SCIENCES

\title{
ANALYSIS OF LEGISLATIVE INITIATIVES TO AMEND THE LAW ON PUBLIC PROCUREMENT
}

\author{
Shpinev Iu. \\ PhD in Law, Senior Researcher in the Sector of Business and Corporate Law, \\ Institute of State and Law of the Russian Academy of Sciences, \\ Moscow, Russian Federation
}

\begin{abstract} customer must approve. the changes are not appropriate.

Recently, more than 25 legislative initiatives have been submitted to the State Duma of the Russian Federation regarding Federal law № 44-FZ of April 5, 2013 «On the contract system for procurement of goods, works, and services for state and municipal needs» [6] (hereinafter referred to As the law on public procurement).
\end{abstract}

Recently, there have been many legislative initiatives to amend the Federal law «On the contract system in the field of procurement of goods, works, and services for state and municipal needs». This article discusses legislative initiatives to amend articles 34 and 93 of this law, according to which if the purchase is made within the framework of a national project, the contract must specify the supplier's obligation to inform the customer of all information about goods, works and services received by subcontractors under the contract in the form that the

Based on the current legislation and analysis of the changes made, the author comes to the conclusion that

Keywords: public procurement, national project, subcontractor, procurement for state needs, penal system

This article discusses two draft laws, the adoption of which, in the opinion of the author, is impractical.

The authors of the first bill propose to introduce amendments to article 34 of the Law on public procurement, adding paragraphs 31 and 32 . According to these amendments, when the purchase is made within the framework of national projects and programs, the state contract must contain a requirement for the supplier (contractor, performer) to notify the customer of the works, services and goods that the co-executors and subcontractors perform under the contract with the main supplier concluded for the purpose of executing the state contract by the latter.

The above information should be provided from suppliers to the customer within 5 days from the date of purchase of the goods (performance of works, rendering of services) under an agreement with the subcontractor or a co-executor of the contract, and in case of failure to provide such information, the changes provide for the recovery from supplier penalty, for each day of failure to provide such information in the amount of the fine in the amount of one three hundredth of the key rate of the Central Bank of the Russian Federation effective on the date the payment of interest, of the price of the contract by the supplier (contractor, state contract with a co-executor or subcontractor in accordance with this part.

In addition, the authors of the bill propose to amend the article 94 of the Law on public procurement part 13, according to which the results of a separate phase of execution of the contract, information on the delivered goods, performed work or provided services under contracts to implement national projects (programmers) is reflected by the customer in the report placed in the unified information system in the manner and form determined by the Government of the Russian Federation.

In the Explanatory note to the draft law [5], the authors indicate that in order to develop the national economy and promote the implementation of national projects and programs, the list of which was approved by the decree of the President of the Russian Federation of may 7, 2018. № 204 «On national goals and strategic development objectives of the Russian Federation for the period up to 2024» (hereinafter-national projects) [4] the draft law was developed in cooperation with the Ministry of industry and trade of the Russian Federation and is aimed at increasing the transparency of purchases of goods, works and services used for the implementation of national projects (programs).

In addition to the changes listed above, the draft law provides for the provision of new reporting forms. Thus, the customer, in accordance with the terms of the contract for the purchase of goods (works, services) concluded for the implementation of national projects (programs), must provide a report on the performance of the contract. The procedure for preparation of the report, placement report in a unified information system and a report form are determined by the Government of the Russian Federation.

According to the authors of the draft law, the analysis of law enforcement practice, which led to the need to change the legal regulation, showed that at present the issues of establishing special conditions for the purchase of goods, works and services for the implementation of national projects (programs) and extending these conditions to contractors are relevant.

The explanatory note also notes that the adoption of the draft law will not require additional allocations from the Federal budget, will not entail socio-economic, financial and other consequences, including for business entities and other economic activities, and will not affect the achievement of the goals of state programs of the Russian Federation budgets of the subjects of the Russian Federation, and the bill itself complies with the provisions of The Treaty on the Eurasian economic Union [8], as well as the provisions of other international treaties of the Russian Federation. 
The State Duma Committee on economic policy, industry, innovative development and entrepreneurship in its Conclusion on this draft law [3] indicated that the draft law provides for liability for failure to provide this information by collecting the corresponding penalty from the supplier (contractor, performer), and it is not clear in what time frame the supplier (contractor, performer) is obliged to provide the customer with relevant information about goods, works, services.

According to the projected part 13 of article 94 of the Federal law, the results of a separate stage of contract execution, information about the goods delivered, work performed, or services rendered under contracts concluded for the implementation of national projects (programs) are reflected by the customer in a report posted in the unified information system in the manner and in the form determined by the Government of the Russian Federation. At the same time, the draft does not address the issue of whether the specified report will be placed in the unified information system in relation to purchases of goods, works, and services, information about the implementation of which is not subject to placement in the unified information system in accordance with Federal law.

In addition, it is necessary to determine when the relevant report should be posted in the unified information system, and also clarify whether the regulation on determining the form of its placement in the unified information system means that the Government of the Russian Federation determines the form of such a report.

In our opinion, the adoption of the draft law under consideration is impractical and raises many questions.

It is not clear why the contractor should provide additional information about subcontractors only when implementing national projects. Have corruption and abuse in the implementation of other projects already been defeated, or are they considered insignificant by the authors?

In any case, the contractor is responsible for the performance of the contract to the customer (in this case, the state) (including the actions of subcontractors and co-executors), and it is unreasonable to load it with additional reports. The state should control the most important sectors of the economy and strategic directions, but this control should not interfere with the flow of ordinary business life [9].

If it is necessary to establish special control or requirements for subcontractors and co-executors engaged by the contractor, these conditions may be subject to separate items in the tender documentation, and assigning additional responsibilities to all performers in the field of national projects without exception seems impractical.

It should also be noted that when concluding a state contract, the General contractor may not know all the subcontractors or suppliers with whom it will cooperate in the project implementation process (and this is quite normal practice), or co-executors or subcontractors may be replaced, including in the case of late or poor-quality performance of their obligations [1].

All the rationale of the bill is reduced to the phrase «Analysis of law enforcement practice, necessitating a change of the legal regulation, showed that the currently topical issues of establishing special conditions for the procurement of goods, works and services for implementation of national projects (programs) and data distribution conditions for contractors» that in no way sheds light on the urgent need of making such a controversial change.

The introduction of additional loads does not lead to any positive results. In the case where the control of sub-contractors is required, it is possible to provide in the tender documentation the contact.

The authors of the second bill propose to amend paragraph 11 of part 1 of article 93 of the Law on public procurement stating it in the following wording:

«production of goods, performance of work, rendering of services is carried out by an institution and (or) enterprise of the criminal Executive system, including exclusively for the needs of the criminal Executive system, in accordance with the list of goods, works, and services approved by the Government of the Russian Federation»».

According to the authors of the bill, it is aimed at strengthening and developing the productive sector of the penal system (hereinafter - MIS), increasing employment of convicted persons and improving the efficiency of use of budgetary funds allocated for the maintenance of the correctional system.

According to the Federal penitentiary service of Russia, currently the number of convicts serving sentences in the form of imprisonment in penal institutions and engaged in paid work is only $40 \%$ or 170 thousand people. UIS has free labor resources from the number of convicts in the number of 254 thousand people.

Production of goods, performance of works, rendering of services by institutions and enterprises of the penitentiary system for internal system needs is one of the main sources of activity of the production sector of the penitentiary system of Russia and labor adaptation of convicts to imprisonment [2].

An increase in the volume of orders for the production of goods, works, and services will increase the amount of profit received from income-generating activities related to attracting convicts to work, which is used for further development of production activities, and, consequently, will lead to a further increase in the number of convicts involved in paid work.

The draft law, according to its authors, gives the Government of the Russian Federation the authority to establish cases when the purchase (performance, provision) of certain goods (works, services) produced (performed, provided) by institutions and enterprises of the penitentiary system can be carried out from such institutions and enterprises as a single supplier (contractor, performer).

The proposed change will increase the number of employed convicts per year with a pessimistic forecast by 720 people, with an optimistic forecast by 3320 people.

There are no Federal budget losses during the adoption of this draft law, since the customer justifies the initial maximum contract price in accordance with legal requirements and enters into a contract at an objectively reasonable price that is valid on the market. 
The proposed changes will not restrict competition, since the right to choose the procurement method (through competitive procedures or from a single supplier) remains the undisputed right of the customer [7].

The socio-economic effect for the year with a pessimistic forecast will amount to 85 million rubles, including 60 million rubles paid to victims at the expense of the salary received by convicts, and 12 million rubles transferred to the budgets of the constituent entities of the Russian Federation and local budgets.

According to the authors of the draft law, the implementation of the provisions will not lead to an increase in the number of employees of the criminal Executive system and will not require an increase in expenditures from the Federal budget, as well as will not entail negative socio-economic, financial and other consequences, including for business entities and other economic activities, and will not affect the achievement of the goals of state programs of the Russian Federation.

In our opinion, the proposed amendments to the Law on public procurement will not affect the change in existing legal relations. Considering the article in the current version, we can conclude that all changes are reduced to the appearance of the Union «(or)» and the addition of the phrase «including exclusively for the needs of the penal system». At the same time, the current version of the law does not in any way prevent enterprises of the penitentiary system from providing services or performing work for their needs, if they are included in the government's list, and the new version does not help simplify this possibility. Thus, the changes made do not affect the scope of their application in any way, and the need to make changes for the sake of changes is controversial.

\section{References}

1. Battakhov P. P. Construction contract in Russia // Bulletin of the Yakut state University. 2008. Vol. 5. No. 3. Pp. 119-121.

2. Cherkesova L. I. Changes in the legal status of the Ministry of Justice of the Russian Federation during the period of legal reforms: dis. ... Kan. the faculty of law. Sciences. Moscow. 1999. 220 p.

3. Conclusion of the State Duma Committee on economic policy, industry, innovative development and entrepreneurship on the draft Federal law № 967343-7 «On amendments to the Federal law «On the contract system in the field of procurement of goods, works, services for state and municipal needs», introduced by member of the Federation Council K. K. Dolgov, Deputy of the State Duma V. V. Gutenev [Electronic resource]. - Access mode-URL: https://sozd.duma.gov.ru/bill/967343-7\#bh_histras (accessed: 11.10.2020).

4. Decree of the President of the Russian Federation № 204 of may 7, 2018 «On national goals and strategic objectives of the development of the Russian Federation for the period up to 2024» / / Rossiyskaya Gazeta. 09.05.2018. № 80.

5. Explanatory note to the draft Federal law «On amendments to the Federal law «on the contract system in the field of procurement of goods, works and services for state and municipal needs». [Electronic resource]. - Access mode-URL: https://sozd.duma.gov.ru/bill/967343-7\#bh_note.

6. Federal law № 44-FZ of April 5, 2013 «On the contract system for procurement of goods, works, and services for state and municipal needs» // Rossiyskaya Gazeta. 12.04.2013. № 80 .

7. Sulakshin S. S., Pogorelko M. Yu., Vilisov M. V., Malchinov A. S., Netesova M. S. Russian doctrines as an act of state administration. Monograph. Moscow. 2012.

8. Treaty on the Eurasian economic Union/ [Electronic resource]. - Access mode-URL: https://www.economy.gov.ru/material/file/2bbbbf9ae33443d533d855bf2225707e/Dogovor_ees.pdf.

9. Zankovsky S. S. Public and private principles in the legal regulation of the economy / / in the collection: Business law in the XXI century: continuity and development. Academic law University at the Institute of state and law of the Russian Academy of Sciences. MZ Press. Moscow. 2002. Pp. 26-41. 